\title{
Effectiveness of Border Surveillance Strategies in the Management of Transnational Terrorism in Kenya and Somalia
}

\author{
${ }^{1}$ Christopher Chumba, ${ }^{2}$ Prof. Pontian Godfrey Okoth, Ph.D. ${ }^{3}$ Dr. Edmond Were, Ph. D \\ ${ }^{1}$ Doctor of Philosophy in Diplomacy and International Relations of Masinde Muliro University of \\ Science and Technology \\ ${ }^{2}$ Masinde Muliro University of Science and Technology (MMUST). \\ ${ }^{3}$ Faculty of Arts and Social Sciences, Kisii University.
}

\begin{abstract}
The shift from diplomacy-based security to security-based diplomacy has been attributed to the fact that generating a comprehensive response to transnational terrorism since September 11, 2001 has proven difficult. There has been an increasing resort to multilateralism and bilateralism in security relations with regard to transnational terrorism. However, the increasing transnational terrorist attacks; particularly terrorist incidences in Kenya with attributes from Somalia have been increasing over time. While the role of military as (a security-based diplomacy approach) has emerged in supporting foreign policy to promote security and deter transnational terrorism, there seems to be a discernable gap between how often each country employs particular military engagement tools. The objective of this study was to Evaluate the effectiveness of border surveillance strategies in the management of transnational terrorism in Kenya and Somalia. An exploratory research design was adopted. The study covered Kenya (Nairobi, Mombasa, Lamu, Garissa and Mandera) and Somalia (Mogadishu, Kismayu and Ras Kamboni). The choice of these regions was centred on the KenyaSomalia relations which have been fraught, often mediated through brute force and mutual suspicion, and mainly viewed as a matter of security; the porous borders as well as the refugee crisis. The total sample size for the study was 400. Sampling techniques used included cluster sampling, and purposive sampling to determine the settings and the participants. Data collection was both interactive (interviews and focus group discussions) and non-interactive involving questionnaire and document analysis. A total of 350 questionnaires were issued to respondents drawn from state and non-state actors, 20 interview guides targeting key informants drawn from state and non-state actors and 30 respondents from religious institutions participated in Focus Group Discussions. Data were analyzed by use of descriptive statistics, through quantitative and qualitative techniques. The study found that the border wall strategy employed by Kenya is viewed as only a short-term strategy that is not overly effective. The study recommended the need for Kenya to reassess its interventionist strategy in Somalia, engage the civil society in counter-radicalization efforts as well as utilizing community intelligence in the management of transnational terrorism.
\end{abstract}

Keywords: Al Qaeda, Al Shabaab, Bilateral security relations, Border surveillance, Community intelligence, Counter radicalization programs, Counter radicalization, Counter radicalization, Deradicalization, Diplomacy, Diplomacy-based security, Extremism, Foreign policy, Fundamentalism, Intelligence community, Intelligence, International community, Islamic Jihadism, Jihadism, Multilateralism, National security, Radicalization, Security-based diplomacy, Small Arms and Light Weapons, Terrorism management, Terrorism, Terrorist radicalization, Threat to national security, Transnational terrorism, Weapon and Weapons of Mass Destruction.

\section{INTRODUCTION}

Since September 11, generating such a comprehensive response has proven difficult. Multilateral approaches have been developed in counterterrorism (Rosand, 2006). For example, the United Nations, the world's foremost multilateral body, has made strides in developing legal and normative means to combat terrorism, yet member states' perceptions of the threat of terrorism remain uneven. Measures taken outside the United Nations the Proliferation Security Initiative, the Financial Action Task Force, and others provide encouraging frameworks, but many are nonbinding and voluntary (Rosand, 2006). According to Chenoweth (2013), the international counterterrorism regime continues to suffer from weaknesses such as inadequate compliance and enforcement of existing instruments and limited resources and expertise (Chenoweth, 2013). While security-based diplomacy is a broad and varying concept that has been understood and implemented in numerous ways, available studies highlight the general importance of security-based diplomacy without linking it to terrorism and hence the need for this study. 
In Africa, emerging security threats to nation-states of Africa hve become a source of problem for most governments in the continent. Further complicating the security landscape is the increase in the outbreak of transnational terrorism that feeds into the so-called terrorist loop in Africa (Onuoha, 2013). The growing audacity of the Nigerian Boko Haram is one among many developments that have made West Africa a region of growing terror concern (Onuocha \& Ezirim, 2013). Salih (2011) argues that the Horn of Africa represents a reverse of the theory of hegemonic stability, in which superpower hegemony deepens rather than lessens political stability. Military operations have been employed in Mali and Nigeria to counter transnational terrorism. In spite of these interventions, transnational terrorism pervades Africa (Onuocha \& Ezirim, 2013). While diplomacy has been used in Africa to combat terrorism, Kwesi (2012) argues that the challenges of lack of an efficient regional and organizational structure, inefficient early warning mechanisms for intelligence and unclear foreign policy objectives and poor coordination have hindered effective progress. Despite this interest, however, it is difficult to gauge the influence of security-based diplomacy in the management of transnational terrorism in the Kenyan and Somali context, hence the need for this study.

The threat of transnational terrorism across Africa and the responses from governments in the region differ in a number of ways and can best be understood in their specific political, cultural and historic contexts. Each country has had its own unique experience with the phenomenon and in countering it, with many having had to confront the threat years before September 2001 (Rosand, 2009). For example, the recent and ongoing terrorism-related activities across North Africa and now moving into the Sahel highlight both the persistence and scope of a threat that affects each country in one form or another and the region as a whole. Despite the considerable efforts by governments in North Africa, there is still a heightened terrorist threat there. A number of terrorist groups are present, most notably al-Qaeda in the Islamic Maghreb (AQIM), that have engaged in suicide bombings, money laundering, smuggling, kidnappings and drug and human trafficking as well as other illicit activities across the neighboring borders of Mauritania, Niger, Libya, Chad and Mali. In fact, the rapid growth of entwined transnational criminal networks operating between North Africa and the Sahel is now threatening the security stability in the region (Rosand, 2009). Yet, there seems to be a dearth of research to examine how security-based diplomacy influences transnational terrorism management in Kenya and Somalia, and hence the need for this study.

Kenya has not been exempted in the terrorist attack trends. The country has been hit severally by acts of terrorism: in 1980 when a bomb destroyed the ballroom of the Jewish-owned Norfolk hotel in Nairobi; August 7, 1998 when the U.S. Embassy was bombed; and November 28, 2002 when terrorists attacked the Israel owned Kikambala Paradise Hotel near Mombasa in the Coast Province (Prestholdt, 2011). Subsequent acts of terrorism on Kenyan soil have been minor in scope when compared to those previous acts. This trend therefore demands for an extensive study and analysis of various factors that motivate terror organizations and the impacts their activities have on the affected states (Bellamy, 2012). The above attacks demonstrate Kenya's significance in terms of recent transnational terrorism. Moreover, the scale and complexity of attacks in Kenya strongly suggests a permissive environment exists for terror group operations. Yet, security-based diplomacy influencing transnational terrorism management in Kenya and Somalia has not been adequately investigated.

A report by Institute for Security Studies (ISS, 2012) indicates that Somali fundamentalist movement, which has been active in Somali politics since the late 1980's, is rooted in the 1950's but was reinforced by state collapse in 1991 and the resultant civil war, international intervention, external influence, and the subsequent efforts made by the Somalis themselves at new patterns of political reconstruction in a bid to shape their own destiny. On the other hand, Kenyan counterterrorism efforts, supported by generous Western assistance, have been at best ineffective and at worst counterproductive. There are strong structural foundations for radicalization in Kenya and Somalia. Radicalization has continued to spread building both on the economic decline, violent conflicts and lack of strong and legitimate states (ISS, 2012). The militant Al-Shabaab movement has built a crossborder presence and a clandestine support network among Muslim populations in the north east and Nairobi and on the coast, and is trying to radicalize and recruit youth from these communities, often capitalizing on long-standing grievances against the central state. This problem could grow more severe with the October 2011 decision by the Kenyan government to intervene directly in Somalia. Radicalization is a grave threat to Kenya's security and stability (Mohamed, 2013). Formulating and executing sound counter-radicalization and de-radicalization policies before it is too late is thus a priority. While counterterrorism is a broad and varying concept that has been understood and 
implemented in numerous ways, available studies on security-based diplomacy and management of terrorism are still sparse and thus a priority area for research.

After the 1998 embassy bombings, Kenya and Tanzania were the primary focus for the US campaign against Al Qaeda, and DoS responded with the East African Counter-Terrorism Initiative (EACTI) and later the East African Regional Strategic Initiative (EARSI) in order to disrupt the flow and activities of violent extremists in the sub-region (2009). However, in the mid-2000s, Somalia was becoming an area of increasing concern for the United States with the rise of violent extremists in the country (Carson, 2010). In response, the US shifted focus and adopted an indirect, but assertive approach in working with sub-regional governments and organizations (AU and IGAD) and with warlords in Somalia against terrorism. However, recent terrorist events have witnessed al-Shabaab continue to exploit divisions within Somalia and Kenya and commit asymmetric attacks to destabilize the country (Worcester, 2013). Consequently, Issacharoff (2014) argues that while diplomacy has undergone profound changes in an era of instant information and greater public access to multiple sources of news and political analysis, the sensitive strategic challenges still impact on states' national security agenda. In the case of Kenya and Somalia, persistent reports of terrorist attacks have deepened concern over the spread of transnational terrorism. As such, it was necessary to interrogate the role of security-based diplomacy in the management of transnational terrorism in Kenya and Somalia.

The September 2013 al-Shabaab attack on Nairobi's Westgate Shopping Mall (and the recent attacks in Lamu and Mandera) have focused the world's attention on Kenya and counterterrorism efforts. Despite Kenya's counterterrorism efforts, the implications of KDF intervention in Somalia raise issues of concern for investigation. Despite the efforts made in management of transnational terrorism, the polarizing tendencies of terrorist radicalization; the intelligence failures on how government agencies interact and share information with one another (Ozzie, 2013) and the underlying challenges of porous borders can hamper the ability of law enforcement to identify and detain potential terrorists. Moreover, while multilateral and bilateral efforts have yielded some positive results, the apparent shift to securitybased diplomacy in the management of transnational terrorism has received little scholarly attention, particularly at the national level. This is why there was need to investigate security-based diplomacy influencing transnational terrorism management in Kenya and Somalia.

\section{Statement of The Problem}

In the recent past, the concept of security-based diplomacy has expanded to become the dominant strategy and is now being emphasized as a counterterrorism measure. This shift from diplomacybased security to security-based diplomacy could be attributed to the fact that generating a comprehensive response to transnational terrorism since September 11, 2001 has proven difficult. Transnational terrorism remains a fundamental threat to national, regional and international peace and security. Overtime, terrorist networks have evolved to the extent that they challenge states' capacity and law enforcement agencies and the tools required to prevent them (Rosendorff \& Sendler, 2012). To a larger extent, the security-based diplomacy approach has been state-centric and for states like Kenya, facing the growth of terrorist attacks, have struggled to balance the need for new security legislation with the worst repercussions from the recent developments in Somalia through military intervention. The coercive strategies employed by the state have not been overly successful since terrorist activities have increased even as more force is employed in attempts to neutralize them (Martin, 2011). Although security-based diplomacy approaches have emerged to promote security and deter transnational terrorism (Rosendorff \& Sendler, 2012), there seems to be a discernable gap in how often each country employs particular military engagement tools.

A security-based diplomacy strategy in counterterrorism in Kenya was launched to ensure a safe and secure environment for sustained socio-economic development. In October, 2011, the KDF deployed its troops to Somalia to respond to numerous Al-Shabaab attacks in Nairobi and subsequent infiltrations into North Eastern during which security personnels were attacked. Although the Government of Kenya was prompted to implement the security-based diplomacy approach as a measure of combat terrorism, the unprecedented reach and potential of terrorist networks such as alshabaab and its affiliates constitute a new danger that still challenges standing tools and institutions charged with providing national security. Counterterrorism measures have been heightened and Kenyan government has been developing a legal architecture through robust military, enhancing the 
structural capacity of intelligence sharing mechanisms, stringent border controls and counter radicalization programs. Yet, this has tended to negatively impact on its relations with Somalia, weighed down on the ground upon which military intervention has been justified and the potential consequences that come with it.

In the recent past, security agencies have been put on the alert following terror attacks. However, the security-based approach faces numerous challenges. Among such challenges include the fraught historical relations between Kenya and Somalia that has been mediated through brute force and mutual suspicion; and mainly viewed as a matter of security that still impacts on the refugee protection in Kenya. In addition, the influences of extremist element in Somalia have since elicited the challenge of youth radicalization following the 'Operation Linda Nchi' initiative bt the Kenya Defence Forces. Furthermore, the structural capacity of intelligence agencies has been questionable owing to terrorist attacks that underscore possible intelligence failures on how government agencies interact and share information with one another. In addition, Kenya's porous borders necessitate a stable environment in which to grow, requiring security and safety (Besteman, 2009). The Somalia-based terrorist group al-Shabaab remains the primary terrorist threat in Kenya and the region at large. Masese et al., (2014: 219) argue that the consequences of the absence of the state in most parts of Somalia in terms of the growth of terrorism are immense. Somali security forces and the AU Mission in Somalia (AMISOM) continue to make gains against al-Shabaab. Despite measures adopted, the threat of terrorism emanating from Somalia remains real (Masese, et al., (2014: 231); (September 2013 attack on Westgate Shopping Mall; June 2014 attacks in Mpeketoni and Mporomooko in Lamu; November 22 attacks where 28 passengers were killed in Mandera; the December 2, 2014 attacks that left 36 people dead at a quarry at Koromey in Mandera County). The recent attack on 15th January 2015 where al Shabaab attacked the Kenya Army (KDF) AMISOM Contingent Forward Operations Base (FOB) manned in El-Adde, Gedo region of Somalia have focused the world's attention on Kenya and Kenyan counterterrorism efforts, highlighting significant shortcomings in the Kenyan security forces. This paper sought to evaluate the effectiveness of border surveillance strategies in the management of transnational terrorism in Kenya and Somalia.

\section{LITERATURE REVIEW}

\subsection{Border Surveillance and Transnational Terrorism Management}

Conceptually, "surveillance" can be viewed from different perspectives. In the context of this study, surveillance is explained as the activity of gathering information on individuals by security agencies within and across the Kenya-Somalia border as a strategy to managing transnational terrorism. First, it includes human and technological gazing where officials watch the physical movements and activities of persons. Second, surveillance involves the acquisition of personal data (Romero, 2003). This includes the collection of biographical, biometric, or transactional data on individuals harvested from personal communications, electronic transactions, identifiers, records, or other documents. In the former, observations can be used for identification or may act to advance an investigation as a component of a larger body of evidence, as in the case of CCTV data. The latter involves voice or documentary information that can be used in criminal investigations or prosecutions (Romero, 2003). Hence, the meaning given to border surveillance here is the collective action of official gathering of information on persons for the stated purpose of preventing crime and transnational terrorism or prosecuting offenders. As the police gather more personal information through surveillance, search, and seizure, a greater number of persons come within their official purview vis-à-vis suspicion profiles, threat assessments, or specific investigations (Romero, 2003). While it has been found that strong technological in border management is key, it is not clear in the context of Kenya-Somalia setup whether a similar scenario exists.

Views of surveillance and privacy have changed dramatically in recent years. Some commentators assert that the U.S. has experienced a progressive shift in the balance between police surveillance authority and individual privacy rights (Chang, 2003). Others cite the terrorist attacks on September 11, 2001 (9/11 hereafter) as a watershed event that provided the catalyst for the widening of police surveillance and search authority (Posner, 2003). The record is replete with examples of U.S. official responses to perceived public safety threats that have precipitated an increase in police surveillance activity (Brown, 2003). However, Kenya-Somalia border security threats pose greater security concerns as far as countering transnational terrorism is concerned. 
Terrorism policies provide evidence that U.S. public safety strategies commonly involve a prominent police surveillance and search role (Abrams, 2005). Faced with modern transnational crime and terrorism, operating in a technologically fluid global environment, the extant official strategy obligates the police to ensure greater public safety under increasingly unpredictable circumstances of porous borders (Posner, 2003). In what Cole (2003:13) refers to as "preventive law enforcement," the legal and operational response has been to use greater surveillance to reduce threats and prosecute transnational offenders. Since the police often lack the manpower and technical expertise to keep pace with global terrorists and criminals, O'Harrow (2005) notes that security agencies need to widen their surveillance capability by collaborating with private commercial enterprises to obtain personal data on the public. Yet, surveillnace capabilities for Kenya and Somalia in light of security-based diplomacy in managing transnational terrorism require further analyses and hence the need for the study.

Controls of cross Border activities on borders require some of the important and strategic heights important for the security of the nation. Both external and internal situations of the country are changing at an incredibly fast pace with the developments in nuclear weapons and missiles, increasing cross border terrorism, the emergence of non-state actors, the growth of Islamic fundamentalists, the narcotics arms nexus, illegal migration and left wing extremism, gravely impacting upon the security of the country and thus posing challenge to management of borders. According to Ford (2005), globalization, media revolution and technological development in various fields have immensely impacted the border management framework. Geocenterality of Kenya and the fear of the unstable neighbouring States of Somalia, economic resources and military strength has impacted on mutual relations. Now more comprehensive planning is needed to achieve peace and progress on borders and hence the need for this study.

\subsection{The Importance of Border Surveillance in Counterterrorism}

Borders serve many vital functions. All legitimate cargo trade passes over these borders, generating customs and other revenues and duties. In this sense, the borders facilitate the flow of trade, which is increasingly important to national economy. Borders are also a "choke point" for monitoring the arrival and departure of people (Carafano, 2004). Mitsilegas (2005) points out that the recent years have witnessed calls for the intensification of surveillance and monitoring of the movement of people globally. These calls, led in particular by the US after the 9/11 events, were also echoed in EU Member States. This intensification of surveillance of movement, realized by both 'widening' (by increasing the transmission of data) and 'deepening' (by introducing biometrics) controls, appears to be at odds with the minimization of checks within many nation (Mitsilegas, 2005). However, some scholars (Haggertyand, 2010) argue that the standards it entails, but also the manner in which these standards have been proposed and adopted, further raise a number of questions regarding legitimacy, democracy and the protection of fundamental rights. Indeed, such concerns intensification of surveillance of movement in Kenya and Somalia call for investigation given the terrorist attacks and threats witnessed in the past.

Surveillance and protection is intended to enable security measures to be taken in the event of threats of risks aimed at individual people, objects or services. The point of departure is safe and unhindered functioning (Haggerty and Ericson, (2010). However, Ginsburg (2006) notes that the term security covers all measures, both policy-related and operational, which focus on preventing attacks on people, objects or services, whether during events or in a specific area, such as an airport. Compared to security, surveillance is more preventive, for example in the form of cameras or guard posts (Ginsburg, 2006). Despite the literature on border surveiilance, an understanding of this phenomenon is important in the Kenyan context, given the shift towards security-based diplomacy in managing transnational terrorism.

Travel and various forms of migration constitute a growing challenge with regard to the monitoring interstate state external borders. From the point of view of counterterrorism, these borders must be guarded effectively enough that terrorists wanting to execute their plans do not have an opportunity to pass these borders without being detected (Ginsburg, 2006). At the same Ford (2005) points out that states have an economic interest in the rapid processing of passenger flows. It goes without saying that border surveillance is a field of work that requires close cooperation with other states and international partners. Despite this mandate, achieving an effective close border coopeartion for Kenya and Somalia in the midst of the more challenging transnational terrorism threat is still a work in progress. 
According to Ball and Webster (2005), terrorist networks are organized and oriented at international level. Actions are, for example, prepared in one country but executed in another. It is very important to terrorists that they can move about freely. Adequate border surveillance functions as an obstacle to the cross border methods of terrorists and terrorist organizations. Within the framework of counterterrorism, proper information exchange between intelligence and security services, an adequate local detection capacity and a specific assessment of incoming and outgoing people are very important. Yet, the existing frameworks in border security and counterterrorism seem to offer only a partial roadmap for security agencies faced with preventing terrrorism against for both Kenya and Somalia and hence the need to investigate security-based diplomacy influencing the management of transnational terrorism in Kenya and Somalia.

\subsection{Strategies Employed in Open Border Control}

The process of securing borders can never be complete, because the environment is too complex and the volume of activity is too great. Carafan (2004) notes that it is prudent to consider what the future of border security might hold as well trends and what issues of policy each countryis likely to confront. However, Rosenblum et al., (2013) observe that understanding border risks begins with identifying key threats. Various strategies in open border control entail surveillance, patrols, joint control operations, information exchange and intelligence assessment. At their roots, border-related threats are closely linked to the flow of people (travelers) and goods (cargo) from one country to another. Any smuggled item or individual hidden among the legitimate flows potentially constitutes a threat to security or interests. The intentions and actions of unauthorized travelers separate them into different threat categories, including terrorists, transnational criminals, and other illegal migrants. Illegal goods are distinguished by their inherent legitimacy or illegitimacy. Certain weapons, illegal drugs, and counterfeit goods are always illegal and categorically prohibited, while other goods are legal under most circumstances, but become illegitimate if they are smuggled to avoid enforcement of specific laws, taxes, or regulations (Rosenblum et al., 2013). Indeed, while efforts towards securing cross-border activities have been enhanced, the transnational nature of terrorism seems to evolve and thus a need for more research on the effectiveness of border surveillance strategies in the management of transnational terrorism in Kenya and Somalia.

In general, (Mitsilegas, 2005), border threats may be divided into actors and goods. Threat actors include potential terrorists, transnational criminals, and unauthorized migrants, threatening goods include weapons of mass destruction (WMD) and certain other weapons, illegal drugs and other contraband, counterfeit products, and products illegally smuggled and/or with potentially harmful effect (Mitsilegas, 2005). While risk management methodologies may be used to analyze a wide variety of threats, this study focused exclusively on the effect of such aspects of border surveillance and how they influence transnational terrorism management in Kenya and Somalia.

The diversity of border threats and the complexity of border security and border management mission create challenges for border security policymaking and planning (Narayan, 2014). These challenges are amplified by the uncertainty and fear surrounding many border threats. Rather than attempting specific predictions about where, when, and how border threats will be realized, analysts often rely on risk management as an approach to border security, and on probabilistic risk models as a framework for analyzing and describing different types of potential threats (Narayan, 2014). On the same note, Carafano (2004) asserts that risk management and risk assessment procedures are rooted in economic theories of consumer behavior and formal models of decision-making that are used in a wide range of industrial, environmental, business, legal, and other settings.

\subsection{Migration Controls and Management of Transnational Terrorism}

Migration controls have become an increasingly important component of counter-terrorism policy over the last few years (Lugna, 2006). After the terrorist attacks on 11 September 2001, strengthening cooperation on migration controls was identified amongst various actions to be taken, but was not given any priority. For instance, at the global level, in the case of EU, Martin (2006) points out that it is only after the terrorist attacks in Madrid in March 2004 that it was identified as a strategic objective in the EU fight against terrorism. Since then, this dimension of the counter-terrorism policy has continued to grow in importance. This trend is set to continue in the future, as a significant number of proposals regarding migration control measures are currently being negotiated in the EU (Lugna, 
2006). However, the development of these initiatives has not been justified by any systematic analysis of the success of migration controls as a counter-terrorism instrument, especially in the developing nations like Kenya and Somalia.

From the viewpoint of counterterrorism, counterespionage, and law enforcement authorities, the borders of states have historically presented rare opportunities to detect and intercept adversaries, who are forced to surface at this point and engage with governmental authorities (Ford, 2005). When terrorist adversaries transit official access points they must take measures to conceal themselves that provide governments and their security partners with opportunities to detect and disrupt them. Ginsburg (2006) argues that legal entry channels visa offices and official ports of entry at land, air, and sea access points located before and at national frontiersare therefore newly critical infrastructure for counterterrorism. They are also critical for responding to pandemics and other security threats and for the safe and efficient management of trade and travel (Ginsberg, 2006). Despite this interest, however, it is difficult to gauge what is actually happening at the border points between Kenya and Somalia and thus the need for more research was needed on the effectiveness of border surveillance strategies in the management of transnational terrorism in Kenya and Somalia.

\subsection{Strategies Employed in Control and Surveillance of the Land Open Border}

Border Management essentially entails controlling and regulating the flow of people, goods and services across a country's borders in the national interest and usually for the maintenance of peace and security. These tasks are typically undertaken by government agencies (Customs and Excise, Immigration and Police) with different combinations of agencies according to the country's laws (Lamptey, 2010). But Kaunert (2010) says that border Management encompasses a complex and dynamic set of activities. In the context of counter-terrorism, effective border management plays an important role in combating the global terrorist threat. Agencies involved in border security and trade facilitation are confronted with the common challenge of facilitating the movement of legitimate people and goods while maintaining controlled and secure borders (Kaunert, 2010). While border management strategies are being employed, Kenya and Somalia still face the challenge of transnational terrorism, and this is why the study sought to examine the effectiveness of border surveillance strategies in the management of transnational terrorism in Kenya and Somalia.

Bures (2006) points out that the United Nations Global Counter-Terrorism Strategy reflects a clear affirmation, on the part of Member States, that effective counter-terrorism measures and the protection of human rights are not conflicting, but rather complimentary and mutually reinforcing goals, and that human rights and the rule of law constitute the fundamental basis of the global counter-terrorism effort. In adopting the Global Strategy and its Plan of Action, Member States resolved "to recognize that international cooperation and any measures that we undertake to prevent and combat terrorism must comply with our obligations under international law, including the Charter of the United Nations and relevant international conventions and protocols, in particular human rights law, refugee law and international humanitarian law" (Bures, 2006). However, the information highlights efforts and strategies that are based on developed systems with well-equipped resources. Yet, developing countries like Kenya and Somalia have inadequate capacity to prevent, mitigate and manage transnational terrorism.

\subsection{Legitimacy and Effectiveness of Border Surveillance}

Rapid globalization has led to increased flows of capital, services, ideas, information and people between countries. As such, problems and challenges that face one nation often have a rippling impact throughout the region and globally. The growing list of cross-border issues cannot be resolved by isolated policy action at the national or sub-national levels. It is essential to forge strategic alliances at the regional level which support the development of consolidated approaches through regional platforms for dialogue and action (Rozemarijn, 2013). According to Cheema (2011), regional governance mechanisms and institutional arrangements to respond to emerging cross-border issues and trends are critical; such as the movement of people including refugees and illegal migrants, regional trade integration for human development, effective and efficient water management, human trafficking, and health focusing on infectious disease surveillance and response (Cheema, 2011). To a broader trend in the literature on counter-terrorism tends to focus more on counter-terrorism strategies such as the use of force or intelligence gathering than on other measures such as migration. 
According to Kaunert (2010), developing a framework for coordinated border management that focuses on the activities of border-control agencies during the pre-arrival, arrival and post-clearance phases of a border crossing is still a challenge for many states. In relation to transnational terrorism management, use of databases specifically, raises the issue of impact on privacy, especially where the data bases might be used to base decisions on: "one impact that's potentially worrying is that the more unified the system is, the more vulnerable it is to privacy. On a range of privacy, discrimination, data protection concerns come up in this respect with harmonization and centralization of data (Rozemarijn, 2013). On the other hand, Argomaniz (2009) argues that the impact of border surveillance should be seen in a broader perspective, especially by comparing the relative importance of the different aims of border surveillance i.e. protecting the border and protecting the lives of the concerned countries. However, Bigo and Tsoukala (2008) point out that the discussion on the legitimacy of border surveillance revolved around three main issues: the procedure by which (the change in) the measure is instigated; the timing and arguments used in that procedure; and the relative importance of the aims of border surveillance. While these studies explore states' efforts to develop a coordinated approach in border management, literature eon border surveillance and management of transnational terrorism in Kenya and Somalia is sparse.

Boswell (2007) asserts that the effectiveness of border surveillance can depended on the definition of the original aim, and whether this aim might have been political: on whether these policies are not effective; whether these border control systems stop people from coming in?' Was that the intention at the beginning. as such, Boswell (2007) views effectiveness to be a measure of the degree to which the measure is able to reach it stated aims. However, it is difficult to establish effectiveness in general as the stated aims might differ depending on one's perspective. In the particular context of border surveillance, effectiveness would be felt to be of little relevance as the goal of protecting borders is, in principle, a worthy cause and therefore the effectiveness of the measure seem to be less relevant, particularly in relation to the discussion of the social acceptability of the measure (Boswell, 2007). The main issues relating to effectiveness, according to Cheema (2011), is that the measurement of effectiveness heavily depends on political agendas and aims. In addition, Bossong argues that measuring effectiveness in the case of counter terrorism is particularly difficult, as it would measure something that is prevented. Effectiveness can also often be referred to in terms of financial costs and benefits (Cheema, 2011). According Baldaccini and Guild (2007), there seems to be little correlation between the effectiveness of a measure and its impact or legitimacy. While efforts to enhance border surveillance have been made, recent local terrorist attacks in Kenya and Somalia suggest renewed trends of transnational terrorism which therefore calls for further investigation.

\subsection{Technology in Border Surveillance in Transnational Terrorism Management}

Given the nature of transnational terrorism, across national borders, security agencies face new challenges in promoting public safety, investigating crimes, and apprehending offenders (Kegley, 2003). Terrorists and criminal offenders have become increasingly adept in the use of technology to perpetrate transnational illegal acts (i.e., terrorism, drug trafficking, human trafficking, organized crime, etc.) (Grabosky and Smith, 1998). Perceived threats, posed by global terrorists and criminals, have provided the impetus for many of the legal changes that have contributed to the enhanced surveillance powers of the U.S. police in recent years (Whitaker, 2003). Changes in technology have contributed to the ability of the police to engage in electronic surveillance of citizens. Personal electronic communications (i.e., internet, voice-over-internet- protocol, cellular telephone, wireless transmission, etc.) are able to be intercepted with greater ease, and to some extent, with less physical intrusion. Therefore, part of the motivation for the police to increasingly adopt the use of electronic technology is to make them more effective at pursuing elusive criminals on a global scale. For this reason, the study sought to look at border surveillance issues such as technology may influence transnational terrorism management between Kenya and Somalia.

Some scholars contend that, unlike past crime threats, modern terrorism poses unique risks to public safety (Hoffman, 2004). Whitaker (2003: 53) describes the modern terrorist as "flexible, adaptable, diversified, transnational, de-centered, a network of networks." Since their motives, objectives, and tactics differ significantly from localized street crime, the police have altered their counter-terrorism approach to crime prevention and public safety (White, 2006). Central to this adaptation is their greater dependence on technology and surveillance to gather and disseminate information (Davis, 2004). Supported by new federal eavesdropping legislation, the police are working to be more effective at gathering a broad range of data on the public. Emerging border surveillance programs 
such as Internet Surveillance are designed to monitor internet traffic and gather user IP addresses, site visitation, and related user activity that are contained in a predetermined "packet" of information. However, as is the case with other counter-terrorism instruments, such as measures are still open to question in the context of security-based diplomacy and hence a priority area for research.

\subsection{Border Communities and Transnational Terrorism Management}

Another key factor that is useful for border management is the inclusion of border communities in the management of the borders. At the local level, most border management efforts do not take advantage of border communities (Kaunert, 2010). in addition, Lamptey (2010) posits that the local community usually has intimate knowledge of the terrain, the criminal syndicates, meeting places and other security issues. Nevertheless, they are not always involved in managing the borders. Their inclusion and incorporation of local perspectives is useful in informing state actors of the threats in the border areas. The gaps created by these omissions are filled by transnational criminal networks. Thus, border agencies must actively involve the local community thereby earning their trust and gradually reducing their reliance on other non-state groups (Lamptey, 2010). While these authros point to community role in border management, it is important to consider this issue in the local context given the significant impact of border communities in Kenya and Somalia in transnational terrorism management.

According to Ginsburg (2006), developing the roles and responsibilities of border personnel so they are effectively engaged in what have been viewed as exclusively intelligence and crime control functions will require adjusting training and career paths among border agencies, between intelligence and screening units, and between agencies primarily dedicated to border functions and full- time intelligence agencies. Similarly, to equip border officers and transit points today with the information and process tools needed to attack terrorist mobility can only be accomplished through a combination of terrorist-specific tools (e.g., a terrorist travel document capability), and general information collection and compliance systems (e.g., establishing a requirement for capturing biometric records of foreign travelers and a system for tracking student visa status) that must be designed for multiple purposes, including counterterrorism (Ball and Webster, 2005).In the case of Kenya and Somalia, persistent reports of terrorist attacks have deepened concern over the spread of transnational terrorism, and such important border management strategies are thus a priority area that made this study relevant.

\subsection{Border Wall as a Strategy in Counterterrorism}

The concept of border security has undergone a sea change with the growing vulnerability of the coastline and also of the airspace. Various countries have employed this stratgy of constructing physicall barriers as walls as a security measure. For example, in an attempt to prevent the kind of violent spillover experienced in Kenya, Saudi Arabia began construction on a 600-mile "Great Wall" along its border with Iraq. Reportedly intended to protect the kingdom from "Islamic State"/ISIS militants, the project was first proposed during Iraq's civil war in 2006. The nascent barrier was already tested in early January when ISIS militants attacked a border post at Arar, reinforcing officials' conviction that the kingdom must be insulated from the chaos engulfing its northern neighbor. This is not the first time Riyadh has sought to secure its borders with a long wall. In 2013, it began construction on a 1,100-mile security barrier along the southwestern border in response to heightened sectarian conflict in Yemen. The multi-billion-dollar barrier, complete with concertina wire, floodlights, and thermal cameras, has reportedly stemmed the flow of terrorists, criminal elements, and economic refugees into the kingdom. Despite this apparent success, the Yemen-based al-Qaeda in the Arabian Peninsula (AQAP) routinely boasts about its ability to infiltrate the border. Regardless of the veracity of AQAP's claims, much remains to be done: areas of lush vegetation and mountainous regions interspersed with deep valleys and Yemeni villages remain difficult for Saudi border guards to patrol (Segawa \& Gilkes, 2015). While these studies explore states' efforts to develop a coordinated approach in border management, literature on border surveillance and management of transnational terrorism in Kenya and Somalia is sparse.

\subsection{Challenges and Obstacles in Border Security and Counterterrorism}

While a great deal of progress is evident, significant challenges and obstacles remain in improving border management and security. Responses to border management challenges in West Africa, for example, at the ECOWAS level, there are some protocols and regulations that provide for 
interventions on border management. The 1999 ECOWAS Protocol relating to the Mechanism for Conflict Prevention, Management and Resolution, Peacekeeping and Security, for instance, under Article 46, talks about control of cross-border crime but makes little mention of related areas of border management (Bassey and Oshita, 2008). The ECOWAS Convention on Small Arms and Light Weapons of 2006 under Article 22 also encourages the strengthening of border controls through subregional cooperation and capacity building but, understandably, it stops short of prescribing a more comprehensive border management strategy such as the AU's draft strategy. The ECOWAS Conflict Prevention Framework in turn emphasizes cross-border initiatives 13 as a means of reducing tensions, fighting cross-border crime and enhancing community welfare, among other concerns. ECOWAS has also been reviewing the Counter- Terrorism Strategy and Implementation Plan in response to the terrorist activities and threat in the region. These initiatives address aspects of border management but do not address comprehensively border insecurity issues as a whole (Lamptey, 2012). Despite these responses to border management, the effectiveness of border surveillance strategies in the management of transnational terrorism in Kenya and Somalia beg for more research and hence such a study.

Lamptey (2010) further argues that despite the challenges and threats posed by border insecurity, there is a lack of a common approach in terms of policy formulation, at the national and sub-regional levels. The AU's strategy, therefore, offers the blueprint from which ECOWAS and national governments can formulate their own context-specific strategies for a more integrated regional response to the challenges of border management. Despite the many challenges associated with the implementation process, the strategy will nevertheless be useful as a starting point for national and regional efforts at border management. However, the primary responsibility for managing borders rests with the state, which must necessarily put in place the structures and policies required to maintain national sovereignty and protect its citizens (Lamptey, 2010). This is why there was need to investigate the role of security-based diplomacy in the management of transnational terrorism in Kenya and Somalia, with border surveillance a key aspect.

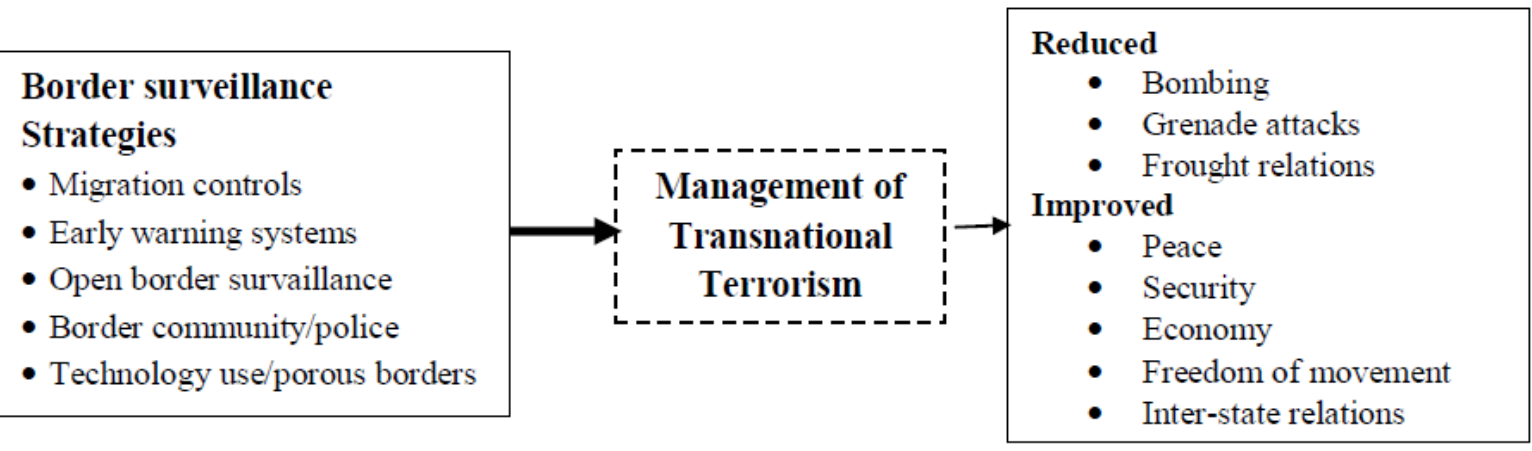

Figure1. Conceptual Framework

\section{RESEARCH MethodologY}

This study first employed an exploratory research design to explore the variables and provide an opportunity for the researcher to collect systematic information on security-based diplomacy influencing management of transnational terrorism in Kenya and Somalia. The study also employed descriptive research design which was geared towards finding the extent to which the study variables on security-based diplomacy influence transnational terrorism management in Kenya and Somalia.

The target population comprised individuals from various institutions as follows: state actors (Foreign Affairs, Ministry of Defense, Ministry of Interior and coordination, Police Headquarters, Kenya and Somalia Embassies, Immigration Officer department; (Kenya-Somalia borders), Non state actors (Media houses, refugee camps, NGOs, Civil society) and religious institutions.

Table1. Distribution of Study Population by Region (Town/ City)

\begin{tabular}{|c|c|c|}
\hline No. & Categories Region & Population \\
\hline 1 & Nairobi & $3,138,136$ \\
\hline 2 & Mombasa & $1,200,090$ \\
\hline 3 & Lamu & 101,539 \\
\hline
\end{tabular}


Effectiveness of Border Surveillance Strategies in the Management of Transnational Terrorism in Kenya and Somalia

\begin{tabular}{|c|c|c|}
\hline \hline 4 & Mandera & $1,025,756$ \\
\hline 5 & Garissa & 623,060 \\
\hline 6 & Mogadishu & $1,353,000$ \\
\hline 7 & Kismayu & 183,300 \\
\hline 8 & Ras Kamboni & 76,000 \\
\hline Total & & $7,700,881$ \\
\hline
\end{tabular}

Source: The World Fact Book (2014)

This study utilized cluster sampling and purposive sampling to determine the settings and the participants. The sample size for the study included 120 from Nairobi, 100 from Mombasa, 24 from Garissa, 28 from Mandera, 42 from Lamu, 36 from Mogadishu, 26 from Kismayu and 24 from Ras Kamboni. The total sample size for the study was 400. Data collection was both interactive (interviews and focus group discussions) and non-interactive involving questionnaire and document analysis. This triangulation enabled the researcher to obtain a variety of information on security-based diplomacy and the management of transnational terrorism in Kenya and Somalia.

Data were analyzed by use of descriptive statistics; through quantitative and qualitative techniques. Qualitative data were drawn from open-ended questions in the questionnaire, document analysis, interview guide and focus group discussions to present the findings. Due to the qualitative impressions and feelings regarding security-based diplomacy influencing transnational terrorism management, they were more likely be suitable for qualitative analysis. The information generated from the analysis was presented through direct quotes. Content and thematic analysis of the information from interviews and FGDs were undertaken to arrive at the objectives. Quantitative analysis involved use of numeric measures to evaluate the role of security-based diplomacy in the management of transnational terrorism in Kenya and Somalia. Analysis was done based on descriptive statistics. Under descriptive statistics, frequencies and percentages were used to describe the data sets and results were presented in tables and charts.

\section{RESULTS AND DISCUSSION}

The findings established that border surveillance plays a critical role in the management of transnational terrorism. This intensification of surveillance of movement, however, is at odds with the minimization of checks and porosity of the borders, which have been blamed for the al Shabaab strategic attacks in Kenya. The findings established that technological advancements in border surveillance were rated to be weak. From the findings, majority from both Kenya and Somalia view Kenya's strategy of building a wall along parts of the border as a short-term strategy that cannot solve underlying problems of terrorism. Strategies employed in control and surveillance of the land open border have not been effective. While Kenya has made strides to tighten border security, inadequate border security cooperation with Somalia coupled with high levels of porosity/undemarcated borders, as well as lack of inclusion of comprehensive patrol units in the management of the border security represented major challenges.

The results reveal travel and various forms of migration controls constitute a growing challenge with regard to the monitoring of Kenya-Somalia external borders. The findings point to issues of corruption that necessitate issuing of passports and national identity cards to criminals and terrorists. The findings reveal ineffective migration controls and challenge point to the vulnerabilities of Kenya and Somalia's efforts to counter terrorism. While surveillance, patrols and physical barriers are common strategies being used, the study established that the involvement of border communities in border security management is low. The inclusion of border communities in the management of the borders was found to be ineffective. At the local level, most border management efforts do not take advantage of border communities.

\section{Conclusions}

The contribution of border surveillance is critical in the management of transnational terrorism. Progress in the homeland security border management has been inconsistent and the extent to which technology adoption is utilized in border surveillance reflects the state capacity to monitor and address underlying cases of corruption and illegal smuggling of goods. Inter-state and local cooperation under border patrol units is still a challenge. Indicators of illegal border crossing and unlawful presence of foreign nationals indicate gaps in the states' efforts to ensuring effective open border patrol strategies. 
Travel and various forms of migration constitute a growing challenge with regard to the monitoring of interstate state external borders. The porosity of Kenya-Somalia border coupled with corruption highlights the challenge of intensifying of stringent migration controls in terms of travel documents which have been blamed for the al Shabaab strategic attacks in Kenya and Somalia. The study established that Kenya's strategy of building a wall along parts of Somalia border cannot offer a longterm strategy in the management of transnational terrorism. A clear border management system that incorporates border communities with a clear and well-communicated border management system is important in building local capacity in the management of transnational terrorism. The study established gaps in border community involvement in border security management. Overall, the study concluded that border surveillance strategies are still a work in progress.

\section{RECOMMENDATIONS}

\subsection{Enhance Border Control Technological Capacity}

The effectiveness of border surveillance in the management of transnational terrorism in Kenya and Somalia can be achieved through appropriate technologies to land, sea and air cross-border movements. Both governments should therefore fund and support the development of security technologies to open new possibilities in the realms of surveillance, identity management and border control. One strategy would involve employing superior technological systems with instant access to GPS and GIS information should along the borders to allow security agents have a wireless access to location to information. Possible Unmanned Aerial Vehicles (UAVs), often referred to as drones, should be employed to enhance surveillance across the Kenya-Somalia. This will require Kenya and Somalia governments to collaborate on providing additional resources and more funding to border security agencies. The best means by which to tackle border infrastructure problems is through investment by the private sector. Not only would this save government resources, it would allow the private sector to use its knowledge and creativity to design border infrastructure that is commercefriendly without jeopardizing security or sovereignty. The government can encourage the private sector to take these steps in a number of ways, for example, by expanding the protections of the Support Anti-Terrorism by Fostering Effective Technologies

\subsection{Integrated Border Patrol Strategy}

Both Kenya and Somalia governments need to evaluate strategies employed in border security to solve underlying security problems instead of relying on the number of arrests. To achieve this, strategis measures should be implemented towards promoting and strengthening border control agencies cooperation and coordination such as organizational and operational cooperation between Kenya and Somalia border patrol units.

\subsection{Streamline Migration Controls}

The study established gaps in migration controls across the Kenya-Somalia border points. To ensure effective migration controls, Kenya and Somalia governments should empower law enforcement and government authorities to monitor and assess security situations with well equipped early warning sytems. This can be achieved through using biometric travel documents and the new screening concepts of identity to track international travel with the goals of preventing identity fraud to ensure safety and security of citizens. Both countries must implement stringent measures to rid out corruption in issuing secure travel documents. The move toward identity and border management will require Kenya and Somalia security agencies to enhance norms in regulating travel documents through widespread adoption of biometric identifiers.

\subsection{Involve Border Communities in Border Security Plans}

Much like state and local governments, private citizens living in border communities recognized the need to take action at the border-because border crimes and illegal immigration were having a direct impact on their neighborhoods and daily lives. The study established that border communities are not fully engaged in border management controls. There is need to identify relevant stakeholders involved in border management and the application of controls. One strategy would be for government and security agencies to partner with border communities in raising awareness and increase sharing of relevant information regarding border management and control as an essential role in countering 
transnational terrorism. For successful implementation of the integrated border mamnagement concept, it is important that Kenya and Somalia security agencies provide coherence among the different communities within and across their borders. Improvements in these areas can help enhance security and immigration systems while also facilitating the cross-border movement of people.

Border ranchers, for instance, had had enough of illegal aliens destroying and stealing fencing and scaring cattle from watering holes. Affected citizens began to organize and take action on their own. One such example is the Minuteman Project-a neighborhood watch group focused on detecting illegal aliens and securing the border.

Overall, the study's findings point to the need to adopt a postmodernist approach which advocates for a broadened conceptualization of security that goes beyond a military fixation on transnational terrorism. This means that both Kenya and Somalia governments must broaden counterterrorism measures to include a wide range of state and non-state actors. In addition to counterradicalization, intelligence sharing and border surveillance, other instruments of government can contribute to addressing the broader long-term causes of transnational terrorism and violent extremism, and the conditions in which they thrive.

While regional cooperation and international support to disrupt insurgencies such as the al-Shabaab in Somalia is needed, there is need for Kenya and Somalia to work with the community to identify, implement and manage local solutions to local problems and to develop local level resilience. This calls for consolidated research to better understand the factors leading to violent extremism in their countries. This can ensure that their work is evidence-based and appropriate to individual state circumstances.

\section{REFERENCES}

Abdi, G. (2014). Federal Government of Somalia. Boulder, CO: Westview Press,

Abera, W. (2013). "Somalia and the recognition to Jubaland administration." Ethiopian Herald. Retrieved 11 September 2013.

Baldaccini, A . and Guild, E. (2007). Terrorism and the Foreigner. Leiden: Martinus Nijhoff.

Ball, K and Webster, F. (2005). The Intensification of Surveillance. London, Pluto Press.

Bassey, C. and Oshita O. (2008). "Governance and Border Security in Africa", Malhouse Press, Lagos: 2010. De Andrés, Amado Philip, "West Africa under Attack: Drugs, Organized Crime, and Terrorism as the New Threats to Global Security", UNISCI Discussion Papers, No. 16.

Bellamy, N. (2005). Anti-Terrorism and Criminal Enforcement, Second Edition, St. Paul, MN: Thomson/West Publishing.

Besteman, N. (2009). Global Migration Governance. Oxford University Press.

Besteman, C. \& Cassanelli, L. (1996). The Struggle for Land in Southern Somalia: The War Behind the War. Boulder, CO: Westview Press.

Bestman, N. (2009). Research in Education: New Delhi: Prentice Hall.

Bigo, D . and Guild, E. (2005). 'Policing at Distance: Schengen Visa Policies' in Bigo, D . and E . Guild, eds, Controlling Frontiers: Free Movement Into and Within Europe. Aldershot: Ashgate .

Boswell, C . (2007). 'Migration Control in Europe after 9/11: Explaining the Absence of Securitization.' Journal of Common Market Studies, 45(3): 589-610 .

Bures, O. (2006). 'EU Counterterrorism Policy: A Paper Tiger?' Terrorism and Political Violence, 18: $57-78$.

Carafano, J. (2004). "No Need for the CLEAR Act: Building Capacity for Immigration Counterterrorism Investigations." Heritage Foundation, Executive Memorandum No. 925, 2142.

Carson, J. (2010a). A Dual Track Approach to Somalia. Center for Strategic and International Studies, Washington, DC, October 20.

Chang, N. (2003). "How Democracy Dies: The War on Our Civil Liberties," in C. Brown (ed.) Lost Liberties: Ashcroft and the Assault on Personal Freedom, pp. 33-51, New York: The New Press.

Chau, D. C. (2010). "The Fourth Point: An Examination of the Influence of Kenyan Somalis in Somalia." Journal of Contemporary African Studies 28, no. 3, 297-312. 
Cheema, S. G. (2011). Cross-Border Governance in Asia: Regional Issues and Mechanisms.UNU: United Nations University Press.

Chenoweth, E. (2013). Terrorism and democracy. Annual Review of Political Science, 16, 355-378.

Chin, C. (2009). "Towards a New Cold War. Culture of Terrorism." The Middle East Journal, Vol. $66(3), 48-9$.

Cole, C. (2003). "Crime-Busting Cameras: A US-City Experiment." The Christian Science Monitor, June 27, 19-22.

Davis, B. (2004). "Spy Gear: Modern Surveillance Tools Use the Newest Technology to Catch Crooks on the Sly." Police, Vol. 28, issue 10: 38-43.

Ford,J. T. (2005). "Improvements Needed to Strengthen U.S. Passport Fraud Detection Efforts." National Strategy for Homeland Security, 3(10), 13-57.

Ginsburg, S. (2006). "Countering Terrorist Mobility: Shaping an Operational Strategy." Foreign Policy, 3, 29-36. 21

Haggerty, K. D. and Ericson, R. V. (2010). "The Surveillant Assemblage' in 51/4." British Journal of Sociology, 2 (3), p. 619.

Kaunert, C . (2007) 'Without the Power of Purse or Sword": The European Arrest Warrant and the Role of the Commission.' Journal of European Integration, 29(4): 387-404.

Kaunert, C. (2010). 'The External Dimension of EU Counter-Terrorism Rela- tions: Competences, Interests, and Institutions.' Terrorism and Political Violence, 22: 41-61.

Kegley, Jr., C. (2003). The New Global Terrorism: Characteristics, Causes and Controls. Upper Saddle River, NJ: Prentice-Hall.

Kwesi, G. W. (2012). The national security strategy of the United States of America. Executive Office Of The President Washington Dc.

Lamptey, A. A. (2010). Rethinking Border Management Strategies in West Africa: Experiences from the Sahel. International Peace Keeping Centre; Policy Brief, 16.

Lugna, L . (2006). "Institutional Framework of the European Union Counter- Terrorism Policy Setting." Baltic Security \& Defence Review, 8: 101-127.

Martin, G . (2006). Understanding Terrorism: Challenges, Perspectives, and Issues, 2nd edition. London: Sage.

Masese, H., Okoth, P. G. \& Onkware, K. (2014). "State failure and the growth of terrorism in Somalia." Journal of Science Technology Education and Management,6 (1\&2),213-232.

Mitsilegas, V . (2007). 'Border Security in the European Union: Towards Centralized Controls and Maximum Surveillance' in Baldaccini, A ., Guild, $E$. and $H$. Toner, eds, Whose Freedom, Security and Justice? EU Immigration and Asylum Law and Policy . Oxford: Hart, 359-394.

Mohamed. S. (2013). Somalia: The Missed Opportunities. Washington: The United Institute of Peace.

Narayan, B. S.(2014). Nepal-India Border Management and Its Challenges and Opportunities. Kuala Lumpur: FIG Congress.

Nye, J. S., \& Lynn-Jones, S. M. (2008). International security studies: a report of a conference on the state of the field. International security, 12(4), 5-27.

O’Harrow, R. (2005). No Place To Hide. New York: Free Press.

Onuoha, F. C. (2012). The audacity of the Boko Haram: Background, analysis and emerging trend. Security Journal, 25(2), 134-151.

Onuoha, F. C., \& Ezirim, G. E. (2013). Terrorism and Trans-national Organised Crime in West Africa. Al Jazeera Centre for Studies.

Ozzie, N. (2013). "Information Sharing in Security and Counterterrorism." Center for Strategic and International Studies, 1, 28.

Posner, G. (2003). Why America Slept: The Failure to Prevent 9/11. New York: Random House.

Prestholdt, J. (2011). Kenya, the United States, and counterterrorism. Africa Today, 57(4), 2-27.

Rosand , E.J. (2009). "Kenya: Risks and Opportunities in Kenya's Intervention in Somalia," International Crisis Group, p. 6-7.

Rosand, E. (2006). The UN-Led Multilateral Institutional Response to Jihadist Terrorism: Is a Global Counterterrorism Body Needed?. Journal of Conflict and Security Law, 11(3), 399-427. 
Rosenblum, M. R., Bjelopera, J. P. \& Finklea, K.M. (2013). "Border Security: Understanding Threats at U.S. Borders." Congressional Research Service, 1-30.

Rosendorff, P. \& Sendler, T. (2012). "The Political Economy of Transnational Terrorism." Turkish Journal of International Relations, Vol. 7, No. 4. 77-84.

Rozemarijn, H. (2013). Civil Society Perspective on the Impact, Legitimacy and Effectiveness of European Counter Terrorism Measures. European Union Seventh Framework Programme: Peace Research Institute Oslo (PRIO).

Salih, M. (2011). Beyond Negotiating a Multipolar World: Sudan's Non-Western Development Cooperation Alternative. African Engagement: Africa Negotiating an Emerging Multipolar World, Leiden, Boston, Brill, 163-182.

Whitaker, R. (2003). “After 9/11: A Surveillance State?” in C. Brown (ed.) Lost Liberties. Personal Freedom, 1, pp. 52-74.

White, H. (2010). Terrorism: International Dimensions. New York: Facts on File.

Worcastor, F. (2013). “Al shabaab: Somaliland security at risk.” RUSI Journal 1(4), 74-5. 